\title{
Dovzhenko V. \\ ASSESSMENT OF QUALITY OF LIFE OF THE RURAL POPULATION IN THE TERRITORY OF RADIOACTIVE CONTAMINATION
}

\begin{abstract}
Проведено аналіз сочіально-економічних параметрів якості життя сільського населення на радіоактивно забруднених територіях. Розглянуто демографічні тендениї̈, рівень захворюваності населення та задоволеності послугами сфери охорони здоров'я. Досліджено житлово-побутові умови проживання населення на території радіоактивного забруднення. Визначено, що доходи населення формуються переважно за рахунок пенсій та заробітної плати, а низький рівень доходів спонукає жителів до самозабезпечення.
\end{abstract}

Ключові слова: якість життя, радіоактивно забрудненні території, демографічна ситуація, житлово-побутові умови, рівень доходів.

\section{Introduction}

Recently, the issue of reviving and returning normal radioactive contamination to the normal life of the area has been increasingly raised. In modern conditions of instability of the political and economic environment of Ukraine, this process requires special approaches to the management of rural territorial communities, have a special status. The ultimate aim of the development of any territory is improvement of the quality of life of its population. For formation of strategic directions for the restoration of production, social and economic processes in the territory of radioactive contamination, it becomes necessary to assess the current level of the quality of life of the rural population in the territory of radioactive contamination in a remote period after the accident.

\section{The object of research and its technological audit}

The object research is socio-economic aspects of the vital activity of the population living in the territory of radioactive contamination.

The quality of life of the population is one of the most important social categories, which is the basis for the concepts of economic growth and development of society. Improving the quality of life of the general public idea is considered as an important priority of the authorities at all levels. To date, the socio-economic parameters of the quality of life of the population living in the territory of radioactive contamination are unsatisfactory, and on the part of the power structures this issue has not been given due attention.

\section{The aim and objectives of research}

The aim of research is analysis of the parameters of the quality of life of the rural population in the territory of radioactive contamination in the remote post-accident period.
To achieve this aim, the following tasks are defined:

1. To conduct an analysis of demographic indicators in the territory of radioactive contamination.

2. To conduct a comprehensive analysis of the level of morbidity and satisfaction with medical services by the population in the territory of radioactive contamination.

3. To characterize the state of housing and living conditions of the rural population.

4. To determine the level and sources of income generation by the rural population in the territory of radioactive contamination.

5. To give recommendations on improving the quality of life of the rural population of radioactively contaminated territories.

\section{Research of existing solutions of the problem}

Scientists are paid attention to the problem of the quality of life in different periods of development of scientific thought. The question remains topical today, when in the conditions of the post-industrial stage of society development the «human factor» becomes the determining factor in economic development. Assessment of the quality of life involves the study of a significant number of quantitative and qualitative indicators, according to [1] requires appropriate information support. In the overwhelming majority of works, it is noted that the assessment of the quality of life is carried out on the basis of objective and subjective approaches [2-4]. Usually, the assessment of the quality of life of the population is carried out for the whole country, at the same time, there are certain regional differences. In particular, [5] notes that socio-economic processes and the moral and psychological climate in the territories exposed to radioactive contamination determine the application of special approaches to the study of the quality of life of the population, where they live.

Significant influence on the socio-economic aspects of the quality of life of the population in the territory of radioactive contamination made changes in the settlement 
network, which they investigate [6] and which also determine the sex and age composition of the population and other demographic indicators reflected in [7]. At the same time, researchers argue that there are territorial differences in the integral index of vitality, which do not depend on the level of radioactive contamination of territories [7]. In [8-10], the economic aspects and the state of the social sphere in the territory of radioactive contamination are considered, and also characterizes the qualitative parameters of the vital activity of the population. However, indicators of the quality of life of the rural population in the territory of radioactive contamination require constant investigation, because in the remote after the Chernobyl nuclear power plant accident the situation in rural areas continues to deteriorate, which requires identifying pressing problems and determining the possibilities for their solution.

\section{Methods of research}

To solve the tasks, the following methods are used: analysis and synthesis, logical generalization, comparative comparison, monographic and graphical representation of the research results.

\section{Research results}

Significant changes in the levels of environmental pollution, food products, socio-economic development of contaminated areas occurred during the 30 -year period after the Chernobyl nuclear power plant accident, but there are no positive trends in the quality of life of rural residents. For the period that has gone through all the efforts of the state were aimed at carrying out anti-radiation countermeasures and social protection of the population, however, due attention was paid to the development of qualitative characteristics of the living conditions of the rural population living in the territory with different levels of radioactive contamination.

The processes of vital activity of households in radioactively contaminated territories occur in conditions of a long-term environmental pollution factor, which causes certain features in formation of the quality of life of the population relative to the region. Proceeding from the foregoing, it can be argued that the quality of life of the rural population of radioactively contaminated territories is mainly determined by ecological processes, therefore its main components are: state of health; consumption of environmentally friendly food; well-being and safe living conditions. The socio-economic consequences of the disaster were reflected in the deterioration of the health of millions of victims, the socio-psychological tensions among the population and demographic changes.

Consequently, the quality of life of the rural population of radioactively contaminated territories characterizes the correspondence of the human habitat to its needs, integrally reflects the average life expectancy, the degree of people's health and the level of their morbidity (physical and psychological) standardized for the population group. To study the socio-economic parameters of the quality of life of the rural population, a sociological study is conducted in the Polissia of the Zhytomyr region, in which 210 respondents (1\% of the total population) - rural residents of critical radioactive contamination of rural settlements in the zone of unconditional (mandatory) resettlement and the zone guaranteed voluntary resettlement of Zhytomyr region. In the course of the study, the respondents (Fig. 1) is determined that the quality of life is closely related to their state of health (5.2 points out of 6 possible) and material situation ( 4.6 points). This situation indicates that rural residents still hope for their own strength in the process of meeting the needs and shaping the conditions of life.

The average score according to the respondents

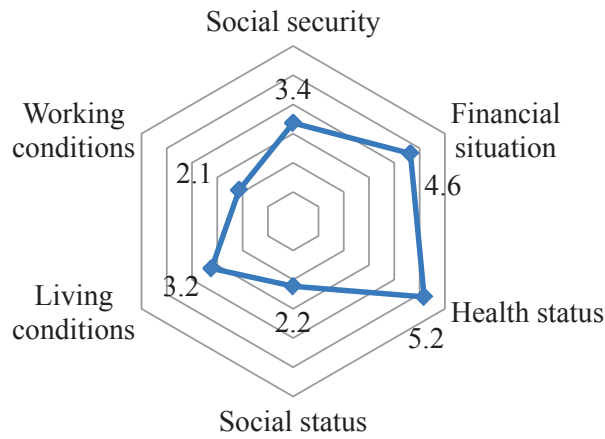

Fig. 1. Assessment interconnection between the quality of life and proposed factors by the rural population of radioactively contaminated territories of the Zhytomyr region. Note: author's research

Rural residents of radioactively contaminated areas believe that social security (3.4 points) and living conditions (3.2 points) also have a significant impact on the quality of life. At the same time, the population of radioactively contaminated territories does not consider the social status as the basis for the qualitative characteristics of their existence, is explained by the migration of a population with a certain status to «conditionally clean» territories. This is also confirmed by the fact that only about $10 \%$ of the rural population in the radioactively contaminated territory has defined their social status as high and elevated. About $50 \%$ of the population assesses the level of social well-being as average, $28 \%$ - lowered and $12 \%$ - low.

Objective assessments of the quality of life primarily include the study of demographic trends. For the period 2002-2016 the population of radioactively contaminated areas of the Zhytomyr region decreased by 80.1 thousand people or by $21.9 \%$. In the context of the regions, the greatest decline in the population is observed in the Malyn district (by $63 \%$ ). Within $20 \%$ of the population was reduced in Korosten, Lugin and Emilchyn district. In the Narodychi district, the area most affected by the Chernobyl accident and which is the least populated, the population decline was $17.9 \%$. The smallest indicator of population decline in Olevsk district is only $10.7 \%$. Taking this into account, one can assert that there is a weak connection between the level of radioactive contamination of the territory and the dynamics of the population in the areas.

To a greater extent, the current trends in the sex-age structure of the population of radioactively contaminated areas are affected by the migration processes that occurred immediately after the accident and those that are observed now. So, unsatisfactory socio-economic conditions in the territory of radioactive contamination caused a significant resettlement of youth and the prevalence of the older 
population, affects the level of fertility. The low standard of living and the inability to receive full-fledged medical services are responsible for the high mortality rate of the population. As a result, a fairly high level of population taminated areas, in particular in rural areas, as compared to the average regional value (Fig. 2). decline is observed in the territory of radioactively con-

In the conditions of reforming the health care system, in recent years, small inter-village hospitals have been closed, including in the territory exposed to radioactive contamination. This situation forces rural people to resort to self-treatment, the use of traditional medicine, resort to medical institutions in the nearest cities, to a certain extent restricts the receipt of full-fledged medical services, a low level of diagnosis of diseases at the initial stages and an increase in the incidence rate.

The study found that the most common diseases of rural residents of radioactively contaminated areas are diseases of the ear, throat, nose, headaches, cardiovascular diseases and diseases of bones and joints. Respondents noted about the presence of chronic diseases:

$14.3 \%$ - cardiovascular diseases;

$11.4 \%$ - diseases of bones and joints;

$5.7 \%$ - headaches;

$4.8 \%$ - diseases of the nervous system.

Most often, with the Chernobyl disaster, rural residents of radioactively contaminated areas associate cardiovascular diseases and headaches, as well as diseases of bones and joints and the circulatory system. It should also be noted that $41.9 \%$ of the respondents interviewed annually undergo a medical examination, but $20 \%$ of respondents do not remember when it was.

In almost all districts exposed to radioactive contamination, the indicator of natural population decline in rural areas is much higher than in the whole territory. The highest level of natural population decline in 2015 was observed in the Narodychi district, it exceeded the average value of this indicator in the region by 2 times. At the same time, in this area in 2015 there was a migration increase in the population, which was 6.1 people per 1.000 people. This indicates that despite adverse environmental and socio-economic conditions in this area, part of the population resettled after the Chernobyl accident returns to their homes. Migration growth in the population is also observed in the Olevsk district. It should also be noted that in Olevsk district, the low rate of natural population decline amounted to 3 people in 2015 and 3.8 people in rural areas per 1.000 of the population. This is due to slightly higher indicators of socio-economic development of the region and better living conditions.

Despite these negative trends in the demographic situation, let's analyze the state of health care and the morbidity level in the rural population of radioactively contaminated territories. It should be noted that for the majority of the rural population of radioactively contaminated areas, the services of paramedic-midwifery stations are the most accessible, of which $43.8 \%$ of respondents indicated in their village. About a quarter of the rural population of radioactively contaminated areas has the opportunity to use the services of pharmacies $(26.7 \%)$ and outpatient $(22.9 \%)$ institutions in the territory of their settlement.
Neoplasms and diseases of the circulatory system are the most common causes of death of the population in the territory of radioactive contamination. So, according to statistical data in the Zhytomyr region in 2015, the high mortality rate caused by neoplasms was observed in the Narodychi district (264.9 people per 100.000 population). The mortality rate due to diseases of the circulatory system was high in Lugin (1631.9) and Narodychi (1589.5) districts.

Most often, according to the results of the survey, rural residents of radioactive contaminated territories receive medical services at their own expense. Only $7.5 \%$ of respondents noted the trust in financing medical services through the health insurance fund. According to the results of the study, it can be argued that the state does not pay enough attention to medical care for the population affected by the Chernobyl accident, since none of the surveyed rural residents used the funds of the Chernobyl Fund for treatment. This is confirmed by the fact that only four people from the respondents recovered last year for the funds of the Chernobyl Fund.

Own efforts are important for health. The study found that almost $70 \%$ of respondents have bad habits. At the same time $74 \%$ of respondents are engaged in improving their health, in particular, $41 \%$ are healthy, $30 \%$ are ecofriendly, $3 \%$ are engaged in sports. However, some of the population have bad habits, negatively affects their health, so, $10 \%$ - regularly drink alcohol, and $21 \%$ - smoke.

The level of public health and the quality of life in general are largely determined by living conditions. Most rural households in the territory of radioactive contamination 
own separate housing. However, the majority of residential premises have a low level of amenities, namely, they are not provided with centralized heating, running water, sewerage, hot water, baths and showers, etc., as evidenced by the results of the survey (Fig. 3).

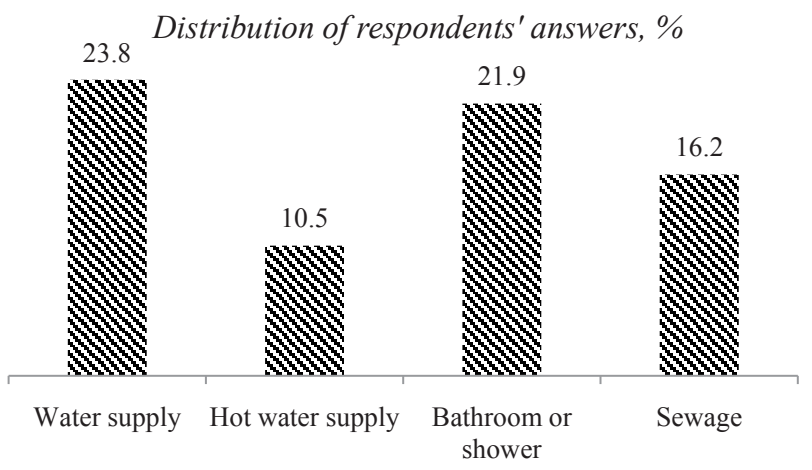

Fig. 3. Provision of residential premises of the rural population of radioactively contaminated territories by amenities. Note: author's research

Only $5.7 \%$ of rural residents believe that their housing does not require any repairs. At the same time, $29.5 \%$ of respondents believe that their housing needs major repairs. A significant part of the living quarters (94 answers of respondents) needs modernization. So, taking into account the research results, it can be concluded that about $90 \%$ of housing in a rural radioactive contaminated area requires modernizing.

The study of the level of consumer services for the population living in radioactively contaminated rural areas allows to conclude that the situation in this sphere is extremely unsatisfactory. In particular, in the territory of nine radioactively contaminated areas of the Zhytomyr region there are only six houses of everyday life ( 4 in Emilchyn district, 2 in Olevsk district) that provide services in sewing (repairing) clothes and shoes; fuel supply; repair of household appliances. In rural settlements, 15 baths and 8 hairdressing salons work in this territory, they also do not satisfy the need for corresponding services, and therefore rural residents are forced to satisfy them independently or outside their settlements.

At the same time, there is a significant differentiation in the income level of the population living in rural settlements in the territory of radioactive contamination. For example, one third of the interviewed respondents noted that the average monthly income per person in their families is from 1.0 to 1.5 thousand UAH. Only $10.5 \%$ of rural families have incomes from 2.0 to 5.0 thousand UAH.

The incomes of rural residents of radioactively contaminated territories are formed mainly at the expense of pension payments (57.1\% of respondents' answers) and wages $(41.9 \%)$. It should also be noted that only $5 \%$ of respondents indicated that they receive cash aid in connection with the restriction of food consumption for citizens affected by the Chernobyl disaster, and $12.4 \%$ of respondents identified social assistance as a source of income. So, less than $20 \%$ of the rural population is covered by various types of social payments in the territory exposed to radioactive contamination. A quarter of the income of rural families in the territory of radioactive contamination is derived from the sale of products grown in subsidiary holdings, and $14.3 \%$ from forest products. This indicates the desire of rural residents to self-sufficiency and self-employment.

\section{SWOT analysis of research results}

Strength of this research is the analysis of the quality of life of the rural population of radioactively contaminated territories with the use of objective and subjective assessments, which makes it possible to obtain scientifically substantiated conclusions regarding demographic trends, incidence and medical services, housing conditions and sources of income generation.

Weaknesses is that the psychological moods of people have a significant impact on the subjective assessments of the quality of life, namely the reluctance to lose the status of the radioactively contaminated territory and the affected population, although the research proves the meager role of these aspects in the formation of social and economic parameters of the rural population in the territory of radioactive contamination.

Opportunities for further research are the development of a special methodology for assessing the quality of life of the population in a remote period after the accident. In particular, the factors that determine the pessimistic mood of the population, and the potential for the revival of socio-economic relations in the territory of radioactive contamination need to be studied.

Threats to the results of the conducted research are that unsatisfactory indicators of the quality of life of the population, a long period of time living in the territory of radioactive contamination, are strengthened by nationwide negative trends in the development of rural territorial communities, sometimes making it impossible to distinguish the influence of the environmental factor.

\section{Conclusions}

1. Research results show that the quality of life of the rural population in the territory of radioactive contamination is based on a combination of objective and subjective assessments of the level of health, living conditions and welfare of the population. At the same time, it is established that the rural population considers the state of health and financial situation as determining factors in the quality of life. At the same time, only $10 \%$ of the rural population defines their social status as high and high, which confirms the existence of social and psychological tensions in the rural areas of radioactively contaminated areas.

2. As a research result it is established that the demographic situation in rural areas in the territory of radioactive contamination in the remote after the emergency period tends to deteriorate. However, the received data testify to insignificant connection between birth rate, death rate and sex-age structure and contamination level of the territory.

3. The incidence rate of the rural population living in environmentally unfavorable conditions is quite high. Population associates cardiovascular diseases, diseases of bones and joints, which are often chronic, and headaches with the effect of radioactive contamination of the territory. The study found that the most accessible in the medical care for the rural population in the territory of radioactive contamination are the services of paramedic-midwife points. It should also be noted that the vast majority of the population receives medical services for their own money. 
4. Most residential premises in rural areas in the territory of radioactive contamination require modernizing (about $90 \%)$. Low is the level of household services for residents of contaminated areas, which is due to the decline of this industry. The income level of the rural population is low, and their differentiation is profound. The survey results show that the main sources of income are wages and pensions, but a significant part of the income (about $40 \%$ ) of the population receives from the sale of forest products and subsidiary farming.

5. So, the ultimate goal of managing the territory of radioactively contaminated rural settlements should be to improve the quality of life of its population. Achieving this goal is possible by reforming medical services, restoring social infrastructure facilities and reviving the region's economy.

\section{References}

1. Radermacher, W. Measuring prosperity and quality of life [Electronic resource] / W. Radermacher // Keynote Speech at the Austrian Federal Ministry of Finance in Vienna, May 2010. April 8, 2010. - Available at: \www/URL: http://ec.europa.eu/ eurostat/documents/118025/118135/wr_speach.pdf/fc3099922367-49b7-9bdb-eb8e5bba2640

2. Libanova, E. M. Vymiriuvannia yakosti zhyttia v Ukraini [Electronic resource]: Analytical Report / E. M. Libanova, O. M. Hladun, L. S. Lisohor et al. - Kyiv: Institute of Demography and Social Studies named after M. V. Ptukha of the National Academy of Sciences of Ukraine, the United Nations Development Program, the Ministry of Economic Development and Trade of Ukraine, 2013. - Available at: \www/URL: http:// www.idss.org.ua/monografii/UNDP_QoL_2013_ukr.pdf

3. Berenger, V. Multidimensional Measures of Well-Being: Standard of Living and Quality of Life Across Countries [Text] / V. Berenger A. Verdier-Chouchane // World Development. - 2007. - Vol. 35, No. 7. - P. 1259-1276. doi:10.1016/j.worlddev.2006.10.011

4. Talalushkina, Yu. N. Kachestvo zhizni naseleniia territorii radioaktivnogo zagriazneniia [Text] / Yu. N. Talalushkina // Vestnik of Orenburg State University. - 2008. - No. 8 (90). - P. 46-49.

5. Talalushkina, Yu. N. Metodika otsenki kachestva zhizni naseleniia territorii radioaktivnogo zagriazneniia [Text] / Yu. N. Talalushkina // Ekonomicheskii zhurnal. - 2015. - No. 4 (40). - P. 15-24.
6. Chemeris, S. L. Changes in the settlement network of radioactively contaminated areas of Zhytomyr region [Text] / S. L. Chemeris // Ekonomichna ta sotsialna heohrafiia. - 2014. - Vol. 2 (70). P. $115-122$

7. Hunko, N. V. Radioaktyvno zabrudneni terytorii Ukrainy: indeks zhyttievosti silskoho naselennia [Text] / N. V. Hunko, N. F. Dubova // Problemy radiatsiinoi medytsyny ta radiobiolohii. - 2012. - Vol. 17. - P. 55-62

8. Dovzhenko, V. Sotsialno-ekonomichne vidrodzhennia radioaktyvno zabrudnenykh silskykh terytorii v umovakh vitchyznianoi modeli detsentralizatsii vlady [Text] / V. Dovzhenko // Bulletin of the Zhytomyr National Agroecological University. 2016. - Vol. 3, No. 1 (55) - P. 346-355.

9. Libanova, E. M. Chornobylka katastrofa: 25 rokiv potomu [Electronic resource] / E. M. Libanova // Sotsialno-demohrafichni naslidky Chornobylskoi katastrofy. - Available at: \www/URL: http://dse.org.ua/arhcive/16/1.pdf

10. Romanchuk, L. Social infrastructure in radioactively contaminated rural territories as the basis of maintaining their activity [Text] / L. Romanchuk, V. Dovzhenko, A. Savych // Bulletin of the Zhytomyr National Agroecological University. - 2016. Vol. 2, No. 2 (57). - P. 3-14

\section{ОЦЕНКА КАЧЕСТВА ЖИЗНИ СЕЛЬСКОГО НАСЕЛЕНИЯ} НА ТЕРРИТОРИИ РАДИОАКТИВНОГО ЗАГРЯЗНЕНИЯ

Проведен анализ социально-экономических параметров качества жизни сельского населения на радиоактивно загрязненных территориях. Рассмотрены демографические тенденции уровень заболеваемости населения и удовлетворенности услугами сферы здравоохранения. Исследовано жилищно-бытовые условия проживания населения на территории радиоактивного загрязнения. Определено, что доходы населения формируются в основном за счет пенсий и заработной платы, а низкий уровень доходов побуждает жителей к самообеспечению.

ключевые слова: качество жизни, радиоактивно загрязненные территории, демографическая ситуация, жилищно-бытовые условия, уровень доходов.

Dovzhenko Valentyna, PhD, Associate Professor, Department of Economic Theory, Intellectual Property and Public Administration, Zhytomyr National Agroecological University,Ukraine,e-mail: vdovzhenko@ukrnet, ORCID: http://orcid.org/0000-0001-7441-3535

\section{Gerasymchuk $N$. SPECIFICS OF DEVELOPMENT AND APPROBATION OF RESOURCE SAVING STRATEGY IN AGRO-INDUSTRIAL COMPLEX}

Обгрунтовано особливості ресурсозбереження для агропромислового комплексу, $i$ відповідно необхідності розробки окремої для иієі сфери економіки стратегії ресурсозбереження. Надані приклади економічної ефективності розробленої стратегії ресурсозбереження для сільськогосподарських підприємств, що були вже апробовані у трьох областях Полтавської області. Застосування представленої стратегї̈ дасть стійке зростання кінщевих результатів функціонування агропромислового комплексу країни, реалізачію основних напрямів забезпечення продовольчої безпеки країни.

Ключові слова: ресурсозберігаючий розвиток, стратегія ресурсозбереження, ресурсовикористання в АПК, підприємства АПК, ресурсозберігаючий механізм.

\section{Introduction}

The effectiveness of resource-saving in agrarian and processing production is inextricably related to the use of innovative methods, technologies, means of labor. The need to solve theoretical and practical problems aimed at identifying and using the reserves of efficiency growth of agro-industrial enterprises by reducing the resource 